\title{
A Review Efficiency of water market and intersectoral water transfer- A macro review and micro analysis
}

\author{
M. Priyanga, S. Achudhan and R. Venkataraman
}

Correspondence to :

\section{Priyanga}

Department of Agriculture

Economics, Annamalai

University, Chidambaram

(T.N.) India

Email : priya93.agri@

gmail.com

Paper History :

Received : 27.12.2017;

Accepted : 24.02.2018
ABSTRACT : Where water is scarce but demand is growing, water markets offer an opportunity to increase economic efficiency by enabling the reallocation of water among users and sectors. While buyers and sellers willingly enter into such transactions, indirect impacts on agricultural communities can be devastating, as intersectoral transfers may substantially alter the nature of the community's underlying economy. Hence, attempt should be made for the gradual conversion of existing informal water markets into formal market. The emergence of formal markets though considered advantageous in economic perspective the other dimensions like social, cultural, institutional and legal should be bestowed due attention owing to their importance in human life.

KEY Words : Efficiency of water, Water market, Intersectoral water, Macro, Micro review

How To Cite This Paper : Priyanga, M., Achudhan, S. and Venkataraman, R. (2018). Efficiency of water market and intersectoral water transfer- A macro review and micro analysis. Internat. Res. J. Agric. Eco. \& Stat., 9 (1) : 224-231, DOI : 10.15740/HAS/IRJAES/9.1/224-231. 